\section{Cyclopentadienyl-tris(trifluorphosphin)-mangan}

In eine Bestrahlungsapparatur der Firma O. Fritz $\mathrm{GmbH}$, Normschliff-Aufbaugeräte, werden $2,0 \mathrm{~g} \quad(9,8$ mMol) $C p M n(C O)_{3}$, gelöst in $340 \mathrm{ml} T H F$, gegeben. Bei $0{ }^{\circ} \mathrm{C}$ wird mit einem Quecksilberhochdruckbrenner TQ 150 der Quarzlampen GmbH, Hanau, bestrahlt, wobei sich die roten THF-Komplexe bilden. Danach läßt man $P F_{3}$ durch die Lösung perlen, bis sie sich nach gelb verfärbt hat. Dann bestrahlt man wieder bei $0^{\circ} \mathrm{C}$ und setzt bei $5^{\circ} \mathrm{C}$ mit $\mathrm{PF}_{3}$ um. Nach der dritten Bestrahlung muß die Temperatur bei der Einwirkung von $\mathrm{PF}_{3}$ auf $20^{\circ} \mathrm{C}$ erhöht werden. Dieses Verfahren wiederholt man sechsmal, wobei die Bestrahlungszeit jeweils $8 \mathrm{Stdn}$. beträgt.

Nach dem Abziehen des Lösungsmittels wird der schmutziggelbe Rückstand in Äther aufgenommen und filtriert. Nach dreimaliger Wiederholung dieser Proze-

1 29. Mitt.: Th. Kruck, G. Sylvester u. I.P. Kunau, Angew. Chem. 83, 725 [1971]; Angew. Chem. internat. Edit. 10, 725 [1971].

2 TH. KRUCK u. L. KNOLL, unveröffentlichte Ergebnisse.

3 TH. KRUCK, Z. Naturforsch. 19 b, 165 [1964].

4 Th. Kruck, W. Hieber u. W. Lang, Angew. Chem. 78, 208 [1966]; Angew. Chem. internat. Edit. 5, 247 [1966].

5 TH. KRUCK u. L. KNOLL, in Vorbereitung.

6 Th. Kruck u. A. Prasch, Z. anorg. allgem. Chem. 356, 118 [1968].

7 M. Herberhold u. C. R. Jablonski, Chem. Ber. 102, 767 [1969]. dur wird bei $40^{\circ} \mathrm{C} / 10^{-3}$ Torr sublimiert. Man erhält gelbe Kristalle von unangenehmem Geruch.

Ausbeute: $2,6 \mathrm{~g}=70 \% \mathrm{~d}$. Theorie.

Schmp.: $165-167^{\circ} \mathrm{C}$.

\begin{tabular}{llllll} 
Analyse: & $\mathrm{H}$ & $\mathrm{C}$ & $\mathrm{F}$ & $\mathrm{P}$ & $\mathrm{N}$ \\
\hline Ber.: & 1,31 & 15,64 & 44,54 & 24,21 & $14,13 \%$ \\
Gef.: & 1,6 & 16,5 & 44,5 & 23,9 & $14,2 \%$
\end{tabular}

MGW (massenspektr.) : 384 .

Unser besonderer Dank gilt dem Ministerium für Wissenschaft und Forschung des Landes NRW, das diese Arbeit finanziell unterstützte, und der Badischen Anilin- \& Sodafabrik AG, Ludwigshafen, für die Ausführung der Elementaranalyse.

8 W. Strohmeier u. F. J. Müller, Chem. Ber. 100, 2812 [1967].

9 J. Müller, K. Fenderl u. B. Mertschek, Chem. Ber. 104, 700 [1971].

10 T. S. Piper, F. A. Cotton u. G. Wilkinson, J. inorg. nuclear Chem. 1, 165 [1955].

11 Für die Aufnahme der Massenspektren danken wir Herrn Dipl.Chem. H. Vilter.

12 Für die Aufnahme der NMR-Spektren danken wir Herrn Dr. P. Junkes.

\title{
Metal Complexes of $N$-hydroxyethylnaphthalideneimine Schiff Base
}

\author{
R. K. Mehta and V. C. Singhi \\ Department of Chemistry, University of Jodhpur, Jodhpur (India) \\ (Z. Naturforsch. 27 b, received September 14, 1971, revised October 2, 1971)
}

\begin{abstract}
The Schiff base, $N$-hydroxyethylnaphthalideneimine forms solid complexes with $\mathrm{Mn}$ (II), $\mathrm{Co}(\mathrm{II}), \mathrm{Ni}(\mathrm{II}), \mathrm{Cu}(\mathrm{II}), \mathrm{Zn}$ (II), Cd(II), $\mathrm{Pd}$ (II) and $\mathrm{UO}_{2}$ (II). The structures of these compounds have been discussed on the basis of their elemental analysis, magnetic moment values and electronic spectral data. These studies have conclusively proved that $\mathrm{UO}_{2}$ (II) and $\mathrm{Mn}$ (II) complexes are octahedral in shape whereas the $\mathrm{Cu}$ (II) complex molecule displays a square planar or tetragonally distorted octahedral configuration. $\mathrm{Co}(\mathrm{II}), \mathrm{Ni}(\mathrm{II}), \mathrm{Zn}$ (II) and $\mathrm{Cd}(\mathrm{II})$ complexes are tetrahedral in structures while the $\mathrm{Pd}(\mathrm{II})$ compound is square planar.
\end{abstract}

Although $N$-aryl and $N$-alkyl salicylideneimines $\mathrm{S} \mathrm{ch}$ if $\mathrm{f}$ bases and their metal complexes have been intensively studied ${ }^{1}$, those of the ligands in which the amino groups are attached to hydroxyalkyl groups have received little attention ${ }^{2,3}$. It is, therefore, considered interesting to study, the metal com. plexes of the $\mathrm{S} \mathrm{ch}$ if $\mathrm{f}$ base derived from 2-hydroxy. 1-napthaldehyde and ethanolamine. The present

Requests for reprints should be sent to Dr. R. K. MentA, Lecturer in Inorganic Chemistry, Department of Chemistry, Univ. of Jodhpur, Jodhpur (Indien). paper describes the results of the investigation on the complexes of $\mathrm{Mn}(\mathrm{II}), \mathrm{Co}(\mathrm{II}), \mathrm{Ni}(\mathrm{II}), \mathrm{Cu}(\mathrm{II})$, $\mathrm{Zn}(\mathrm{II}), \mathrm{Cd}(\mathrm{II}), \mathrm{Pd}(\mathrm{II})$ and $\mathrm{UO}_{2}$ (II) with $N$-hydroxyethylnaphthalideneimine $\mathrm{Sch}$ iff base and these are represented by the Structures I and II.

\section{Experimental}

Materials: $N$-hydroxyethylnaphthalideneimine was prepared by boiling a mixture of equimolecular proportions of 2-hydroxy-1-naphthaldehyde and ethanolamine in dry benzene over a waterbath under reflux for two 
hours. Afterwards, excess of benzene was distilled off and the solid residue was extracted into methanol. The clear solution was filtered, concentrated and cooled when yellow crystals of $\mathrm{S} \mathrm{ch}$ if $\mathrm{f}$ base were obtained. These were filtered out and recrystallised from methanol, m.p. $145^{\circ} \mathrm{C}$. Found: C $72.41, \mathrm{H} 6.02$, N 6.49 , $\left[\mathrm{C}_{10} \mathrm{H}_{6}(\mathrm{OH}) \mathrm{CH}=\mathrm{N}\left(\mathrm{CH}_{2}\right)_{2} \mathrm{OH}\right]$ requires $\mathrm{C} 72.55, \mathrm{H}$ 6.05 , and $\mathrm{N} 6.51 \%$.

The complexes of $\mathrm{Mn}$ (II), Co(II), $\mathrm{Ni}(\mathrm{II}), \mathrm{Cu}(\mathrm{II})$, $\mathrm{Zn}$ (II), Cd(II), Pd(II), and $\mathrm{UO}_{2}$ (II) with $N$-hydroxyethylnaphthalideneimine were prepared by the method of YAMADA et al. ${ }^{4}$.

All these compounds are found to be insoluble in water but partially soluble in alcohol, pyridine and other organic solvents.

Measurements: The combustion analysis was conducted by using Hosli's electrical micro combustion furnace. Gallenkamp Semi-micro ebulliometer was employed for molecular weight determinations using ethanol as the solvent. The magnetic measurements were made on Gouy apparatus. Diamagnetic corrections were applied and finally the molar susceptibility and magnetic moment were evaluated at $303^{\circ} \mathrm{K}$. The electronic absorption spectra of the complexes in solution were determined with a VEB Carl Zeiss Jena, VSU-2P spectrophotometer at room temperature.

Colour, molecular weight and elemental analyses data of these compounds are given in Table 1 and the magnetic data in Table 2.

\section{Results and Discussion}

Manganese (II) Complex: It corresponds to the composition $\left[\mathrm{MnL}_{2}\right]$ where $\mathrm{LH}=\left[\mathrm{C}_{10} \mathrm{H}_{6}(\mathrm{OH}) \mathrm{CH}\right.$ $\left.=\mathrm{N}\left(\mathrm{CH}_{2}\right)_{2} \mathrm{OH}\right]$ and its magnetic moment is found to be 5.83 B.M. at room temperature $\left(30^{\circ} \mathrm{C}\right)$. The magnetic moments of both octahedral or tetrahedral Mn(II) compounds should be nearly 5.92 B.M. since a ${ }^{6} \mathrm{~S}$ ground state persists in all symmetries of Mn(II) complexes ${ }^{5}$. The little lower value of the magnetic moment of this compound may be due to spin exchange in its solid state or to the presence of little Mn(II) species which may be caused due to aerial oxidation as reported earlier ${ }^{1}$ for such complexes.

In order to decide whether hexacoordination is due to intermolecular association or to intramolecular combination of $-\mathrm{OH}$ group with the central $\mathrm{Mn}(\mathrm{II})$, the knowledge pertaining to its molecular weight is quite helpful. The molecular weight of the $\mathrm{Mn}$ (II) complex under investigation is found to be 475 which excludes the probability of intermolecular association and it is most likely that the intramolecular $\mathrm{M}-\mathrm{OH}$ bond may be present in the compound. This situation is best represented by an octa- hedral structure for the $\mathrm{Mn}$ (II) complex which seems to have been favoured by steric condition.

Thus based on elemental analysis, molecular weight and magnetic results an octahedral structure is assigned to this complex in which the third coordination position of the $\mathrm{Mn}$ (II) is occupied by the $-\mathrm{OH}$ group and the $\mathrm{Sch}$ if $\mathrm{f}$ base functions as a tridentate ligand (Fig. 1).

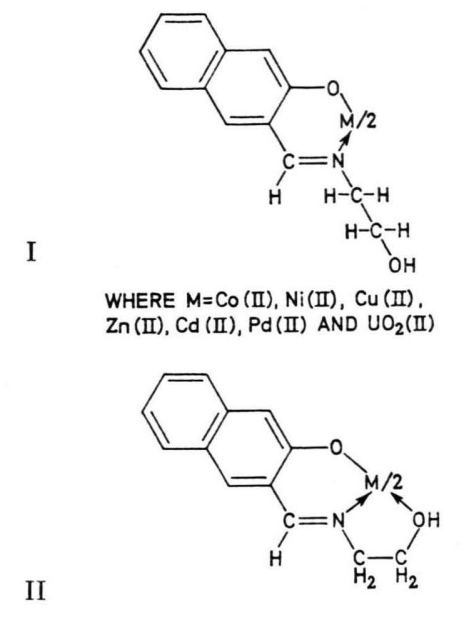

WHERE $M=M n$ (II)

Cobalt(II) Complex: The data summarized in Table 1, give the composition $\left[\mathrm{CoL}_{2}\right]$ for this compound in which $\mathrm{LH}=\left[\mathrm{C}_{10} \mathrm{H}_{6}(\mathrm{OH}) \mathrm{CH}=\mathrm{N}\left(\mathrm{CH}_{2}\right)_{2} \mathrm{OH}\right]$ and thus indicate $1: 2$ metal-ligand stoichiometry in it. The magnetic moment of this compound at room temperature $\left(30^{\circ} \mathrm{C}\right)$ is found to be 4.61 B.M. The electronic absorption spectra of this complex in dioxane and pyridine consist of only one absorption band with its peak at $13,700 \mathrm{~cm}^{-1}$. The band may be assigned to the transition ${ }^{4} \mathrm{~T}_{1} \leftarrow{ }^{4} \mathrm{~A}_{2}$ which may be due to the tetrahedral configuration of the complex. Thus based on molecular weight spectral and magnetic data a high-spin tetrahedral structure (I) is assigned to the Co(II) complex under study, in which the $\mathrm{Schiff}$ base functions as a bidentate ligand.

Ni(II) Complex: The greenish yellow $\mathrm{Ni}$ (II) complex displaying a metal-ligand ratio of $1: 2$, can be represented by the formula $\left[\mathrm{NiL}_{2}\right]$, where $\mathrm{LH}=\left[\mathrm{C}_{10} \mathrm{H}_{6}(\mathrm{OH}) \mathrm{CH}=\mathrm{N}\left(\mathrm{CH}_{2}\right)_{2} \mathrm{OH}\right]$. The magnetic moment of this compound at room temperature $\left(30^{\circ} \mathrm{C}\right)$ is found to be 3.82 B.M. In a four covalent, paramagnetic, high-spin, tetrahedral $\mathrm{Ni}(\mathrm{II})$ complex the ground term is ${ }^{3} \mathrm{~T}_{1}$ and the moments lie 


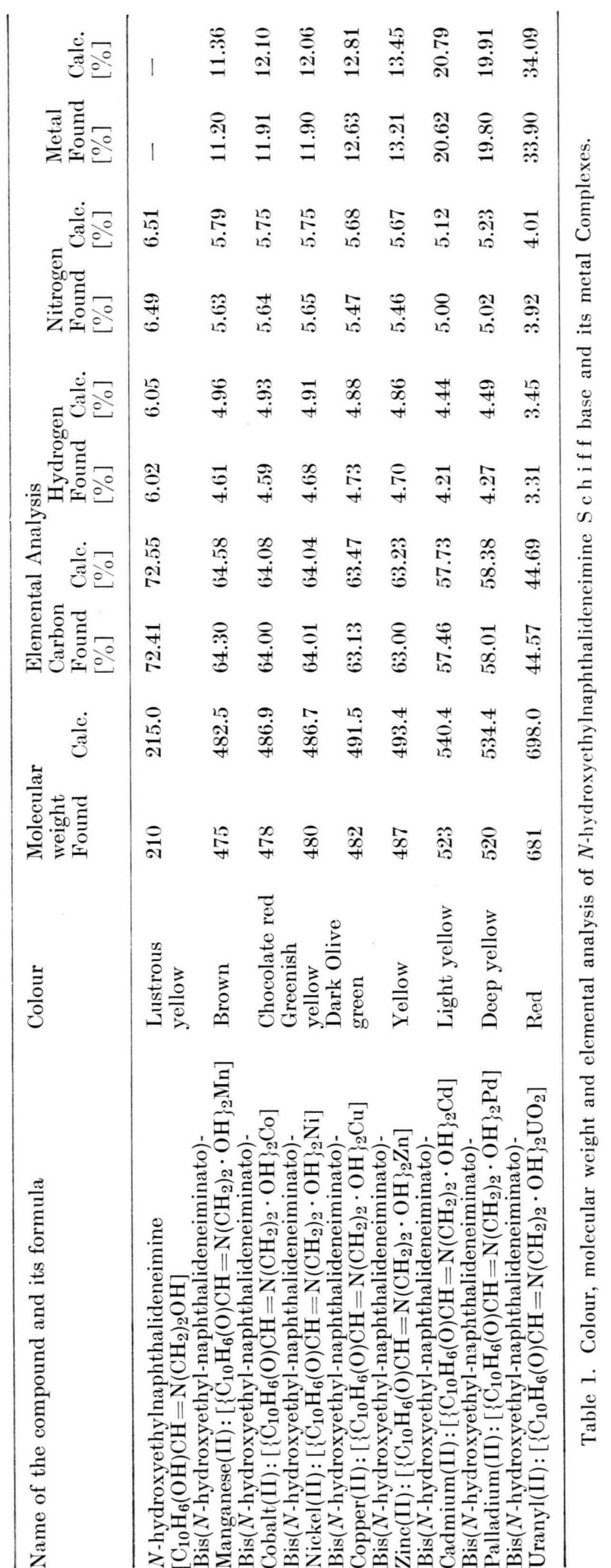

between 3.2 and 4.0 B.M. at room temperature. Based on this the $\mathrm{Ni}$ (II) compound under study should display tetrahedral configuration (I) in which the ligand acts as a bidentate one.

Copper(II) Complex: The molecular weight and the elemental analyses (Table 1) of the olive-green copper(II) compound suggest 1:2 metal-ligand stoichiometry. Its composition may therefore be given by $\left[\mathrm{CuL}_{2}\right]$ where $\mathrm{LH}=\left[\mathrm{C}_{10} \mathrm{H}_{6}(\mathrm{OH}) \mathrm{CH}=\right.$ $\left.\mathrm{N}\left(\mathrm{CH}_{2}\right)_{2} \mathrm{OH}\right]$. The molecular weight results clearly indicate its existence as a monomer in the solid state. The copper(II) complex under study exhibits a magnetic moment of 1.87 B.M. at room temperature $\left(30^{\circ} \mathrm{C}\right)$. The magnetic-moment of planar-complexes are generally lower $(1.8-1.9$ B.M. $)$ than those of octahedral complexes $\left(\mu_{\mathrm{eff}} \approx 1.9-2.0\right.$ B.M.). As planar stereochemistry may be considered as the limiting case of a tetragonally distorted octahedral stereochemistry, the separation of the interaction terms (i.e. between ground term ${ }^{2} \mathrm{~B}_{1 \mathrm{~g}}$ and the components of ${ }^{2} \mathrm{~T}_{2 g}$ term) is large in squareplanar complexes than in octahedral complexes which possibly explains the lower magnetic moments of square-planar complexes ${ }^{5,6}$. The magnetic moments of perfect tetrahedral complexes are higher than square planar or octahedral complexes due to spin-orbit coupling and are temperature dependent. The electronic absorption spectra in methanol of the Copper(II) compound consists of a broad band at about $16750 \mathrm{~cm}^{-1}$ and second band at $24210 \mathrm{~cm}^{-1}$. The appearance of an absorption band at 16750 $\mathrm{cm}^{-1}$ and the magnetic moment value of 1.87 B.M., support a square planar or tetragonally distorted octahedral configuration of the complex ${ }^{7,8}$. The band exhibit bathochromic shift in pyridine which may be attributed to the association of two pyridine molecules to the $\mathrm{Cu}$ (II) ion thus forming an octahedral complex. The Schiff base appears to exhibit bidentate function in this case.

\section{Zinc(II), Cadmium(II), Uranyl(II) and Palla- dium(II) Complexes}

These compounds were found diamagnetic, as expected and possess 1:2 metal-ligand stoichiometry as supported by their elemental analysis and molecular weight data. Thus their composition may be expressed by $\left[\left\{\mathrm{C}_{10} \mathrm{H}_{6}(\mathrm{O}) \mathrm{CH}=\mathrm{N}\left(\mathrm{CH}_{2}\right)_{2} \mathrm{OH}\right\}_{2} \mathrm{M}(\mathrm{II})\right]$, where $\mathrm{M}$ stands for $\mathrm{Zn}(\mathrm{II}), \mathrm{Cd}(\mathrm{II}), \mathrm{UO}_{2}$ (II) and $\mathrm{Pd}(\mathrm{II})$. Consequently $\mathrm{Zn}(\mathrm{II})$ and $\mathrm{Cd}(\mathrm{II})$ com- 


\begin{tabular}{|c|c|c|c|c|c|}
\hline Formulae & $\begin{array}{l}\text { Mass Sus- } \\
\text { ceptibility } \\
\chi_{\mathrm{s}} \times 10^{6}\end{array}$ & $\begin{array}{l}\text { Molar Sus- } \\
\text { ceptibility } \\
\chi_{\mathrm{m}} \times 10^{6}\end{array}$ & $\begin{array}{l}\text { Magnetic } \\
\text { Moments } \\
\mu_{\text {eff in B.M. }}\end{array}$ & $\begin{array}{l}\text { No. of } \\
\text { unpaired } \\
\text { electrons }\end{array}$ & $\begin{array}{l}\text { Possible } \\
\text { bond type }\end{array}$ \\
\hline $\begin{array}{l}{\left[\left\{\mathrm{C}_{10} \mathrm{H}_{6}(\mathrm{O}) \mathrm{CH}=\mathrm{N}\left(\mathrm{CH}_{2}\right)_{2} \mathrm{OH}\right\}_{2} \mathrm{Mn}\right]} \\
{\left[\left\{\mathrm{C}_{10} \mathrm{H}_{6}(\mathrm{O}) \mathrm{CH}=\mathrm{N}\left(\mathrm{OH}_{2}\right)_{2} \mathrm{OH}\right\}_{2} \mathrm{Co}\right]} \\
{\left[\left\{\mathrm{C}_{10} \mathrm{H}_{6}(\mathrm{O}) \mathrm{CH}=\mathrm{N}\left(\mathrm{CH}_{2}\right)_{2} \mathrm{OH}\right\}_{2} \mathrm{Ni}\right]} \\
{\left[\left\{\mathrm{C}_{10} \mathrm{H}_{6}(\mathrm{O}) \mathrm{CH}=\mathrm{N}\left(\mathrm{CH}_{2}\right)_{2} \mathrm{OH}\right\}_{2} \mathrm{Cu}\right]} \\
{\left[\left\{\mathrm{C}_{10} \mathrm{H}_{6}(\mathrm{O}) \mathrm{CH}=\mathrm{N}\left(\mathrm{CH}_{2}\right)_{2} \mathrm{OH}\right\}_{2} \mathrm{Zn}\right]} \\
{\left[\left\{\mathrm{C}_{10} \mathrm{H}_{6}(\mathrm{O}) \mathrm{CH}=\mathrm{N}\left(\mathrm{CH}_{2}\right)_{2} \mathrm{OH}\right\}_{2} \mathrm{Cd}\right]} \\
{\left[\left\{\mathrm{C}_{10} \mathrm{H}_{6}(\mathrm{O}) \mathrm{CH}=\mathrm{N}\left(\mathrm{CH}_{2}\right)_{2} \mathrm{OH}\right\}_{2} \mathrm{Pd}\right]} \\
{\left[\left\{\mathrm{C}_{10} \mathrm{H}_{6}(\mathrm{O}) \mathrm{CH}=\mathrm{N}\left(\mathrm{CH}_{2}\right)_{2} \mathrm{OH}\right\}_{2} \mathrm{UO}_{2}\right]}\end{array}$ & $\begin{array}{l}28.2767 \\
17.3498 \\
11.7577 \\
2.4057 \\
- \\
- \\
-\end{array}$ & $\begin{array}{l}13658.34 \\
8447.60 \\
5722.54 \\
118242 \\
- \\
- \\
-\end{array}$ & $\begin{array}{l}5.83 \\
4.61 \\
3.82 \\
1.87 \\
\text { diamagnetic } \\
\text { diamagnetic } \\
\text { diamagnetic } \\
\text { diamagnetic }\end{array}$ & $\begin{array}{l}5 \\
3 \\
2 \\
1\end{array}$ & $\begin{array}{l}\mathrm{sp}^{3} \mathrm{~d}^{2} \\
\mathrm{sp}^{3} \\
\mathrm{sp}^{3} \\
\mathrm{sp}^{3}\end{array}$ \\
\hline
\end{tabular}

Table 2. Magnetic data of the complexes of $N$-hydroxyethylnaphthalideneimine $\mathrm{Sch}$ if f base at $303^{\circ} \mathrm{K}$.

pounds possess tetrahedral configuration in which the $\mathrm{Schiff}$ base functions as a bidentate ligand. $\mathrm{UO}_{2}$ (II) complex, probably possesses an octahedral structure as is usually displayed by $\mathrm{UO}_{2}$ (II) ${ }^{9}$. In this complex the $\mathrm{S} \mathrm{ch}$ iff base acts as a bidentate ligand. Pd(II) greatly favours a square planar configuration. YAMADA et al. ${ }^{10}$ have suggested square planar structure for a number of $N$-alkylsalicylideneiminato $\mathrm{Pd}$ (II) complexes. A similar structure is suggested for the $\mathrm{Pd}(\mathrm{II})$ complex under investigation, in which the $\mathrm{Schiff}$ base functions as a bidentate ligand. The solution spectra of $\operatorname{Pd}(\mathrm{II})$

1 R. H. Holm, G. W. Everette, JR., and A. Chakravorty, Prog. Inorg. Chem. 7, 83 [1966].

2 S. Yamada, S. Kuge, and K. Yamanouchi, Bull. Chem. Soc. Japan 40, 1864 [1967].

3 S. N. Poddar, K. Day, J. Haldar, and Nathsarkar, J. Indian Chem. Soc. 47, 743 [1970].

4 S. Yamada, H. Nishikawa, and E. Yoshida, Bull. Chem. Soc. Japan 39, 994 [1966].

5 B. N. Figgis and C. M. Harris, J. chem. Soc. [London] $1959,855$. complex in methanol and pyridine showed negligible difference which indicates that the pyridine molecules do not coordinate to the central Pd(II) ion and these results agree with those of YAMADA et al. ${ }^{10}$.

The configurations reported in this communication are in agreement with those of $N$-hydroxy. ethylsalicylideneimine complexes ${ }^{3}$ with which it is structurally similar.

The authors are thankful to University Grants Commission New Delhi (India) for the award of a fellow. ship to one of them (V.C.S.).

${ }^{6}$ B. N. Figgis and J. Lewis, Prog. Inorg. Chem. 6, 37 [1964].

7 L. Sacconi and M. Ciampolini, J. chem. Soc. [London] 1964, 276.

8 L. Sacconi et al., J. Inorg. Nucl. Chem. 19, 73 [1961].

9 J. Sflbin, Angew. Chem. internat. edn. 5, 712 [1966].

10 S. Yamada, Coordin. Chem. Rev. 1, 415 [1966]. 